\title{
Dose Assessment of workers long term exposed to chronic intakes of enriched uranium
}

\author{
María Antonia López $^{1, *}$, Soledad Sierra $^{2}$, Inmaculada Sierra ${ }^{1}$, Carolina Hernández ${ }^{1}$, Daniel \\ Garcia $^{2}$, Agustín Pérez ${ }^{2}$ \\ ${ }^{1}$ CIEMAT, Internal Dosimetry, Avda.Complutense 40, 28040 Madrid, Spain \\ ${ }^{2}$ ENUSA, Fábrica de elementos combustibles, Carreterade Salamanca a Ledesma km26, 37115 \\ Juzbado (Salamanca), Spain
}

CIEMAT Internal Dosimetry Service started in 2014 an individual monitoring program of in vitro bioassay measurements of low enriched uranium in urine by radiochemical procedure and alpha spectrometry, for workers involved in the fabrication of nuclear fuel elements for Spanish Nuclear Power Plants.

A total of 198 workers at risk of internal exposures in the Juzbado facility of ENUSA in Salamanca (Spain) have been included in routine, task-related or confirmatory monitoring programs, providing $24 \mathrm{~h}$ urine samples for the determination of the daily excreted activity of ${ }^{234} \mathrm{U},{ }^{238} \mathrm{U}$ and ${ }^{235} \mathrm{U}$, with a Minimum Detectable Amount (MDA) of $0.5 \mathrm{mBq} / \mathrm{d}$ for each isotope. A "blank" urine sample of the new employees at the ENUSA workplace is obtained prior to start working in areas at risk of internal exposure for background subtraction. A study of the dietary contribution of natural uranium in the area is in process.

The monitoring data of 72 workers obtained in 2014 suggested a scenario of chronic intakes through inhalation of low enriched uranium at Juzbado facility. Currently workers identified at risk of internal exposure in the plant are monitored in routine at CIEMAT Bioassay laboratory in Madrid, $250 \mathrm{~km}$ from Juzbado. Excreta samples preserved in nitric acid are transported from Salamanca to Madrid. A creatinine test for the validation of $24 \mathrm{~h}$ excretion is performed and correction of daily activity rate is carried out accordingly. Taking into account the available equipment and human resources of CIEMAT internal dosimetry service for measurements and dose assessments, frequency of monitoring was established according to first results of Committed Effective Dose E(50) obtained in 2014, being annual monitoring in case of $\mathrm{E}(50)<5 \mathrm{mSv}$ and semi-annual monitoring when $\mathrm{E}(50)>5 \mathrm{mSv}$.

CIEMAT established a methodology for dose evaluation based on IDEAS Guidelines [1] and ISO 16638-Part 1 [2], using IMBA software (v 4.1.60). Chronic inhalation of low enriched uranium since the beginning of internal exposure of each worker at the Juzbado fabric was assumed. The intake scenario consists in Uranium oxides, type S of solubility and a particle size of $5 \mu \mathrm{m}$ of AMAD (default value recommended by ICRP). Dose assessment was carried out in an ICRP78/ICRP119 frame for occupational exposures.

Interpretation of monitoring data takes account of type A and type B uncertainties by calculating the corresponding Scattering Factor [1] of each measurement result, for intake estimation. The Chi squares test is used for confirming the goodness of fit of the monitoring data with the prediction of the excretion model for the assessed intake and permits to corroborate the conditions and assumptions of the internal exposure at the workplace.

\footnotetext{
*Corresponding author: ma.lopez@ciemat.es
} 
Intake and dose $\mathrm{E}(50)$ are obtained separately for ${ }^{234} \mathrm{U}$ and ${ }^{238} \mathrm{U}$ when activity concentration $(\mathrm{Bq} / \mathrm{d})$ is above MDA. Total Intake of enriched uranium is estimated using isotopic composition of low enriched uranium by ISO 16638 Part 1[2] (82\% alpha activity corresponds to ${ }^{234} \mathrm{U}$ ) for calculating the intakes of uranium isotopes whose data are below MDA. Dose contributions of annual chronic intakes were assessed for 106 workers with results $>$ MDA. Results of $\mathrm{E}(50)>1 \mathrm{mSv} /$ year are reported to workers. In case of partial annual exposures, doses of $\mathrm{E}(50)>0.2 \mathrm{mSv}$ are also reported.

This publication focuses on the group of 37 workers chronically exposed to the inhalation of enriched uranium during 30 years. Bioassay monitoring data obtained in the period 2014-2018 resulted in daily excreted activities in the range of $1-15 \mathrm{mBq} / \mathrm{d}$ of ${ }^{234} \mathrm{U}$ in urine for this long term exposed staff. Isotopic composition of excreta samples confirmed the intakes of low enriched uranium, with an average ${ }^{234} \mathrm{U} /{ }^{238} \mathrm{U}$ ratio of 4.4 of urine activity rate. Annual chronic intakes with doses $\mathrm{E}(50)$ above $1 \mathrm{mSv} /$ year were detected in $50 \%$ of the cases (see Figure 1). Maximum annual intake corresponds to one worker exposed since 1985 , with $\mathrm{E}(50)=5 \mathrm{mSv} /$ year.

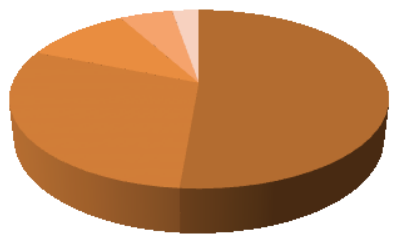

$$
\begin{aligned}
& \square(50)<1 \mathrm{mSv} / \mathrm{y} \\
& \square \mathrm{mSv} / \mathrm{y}<\mathrm{E}(50)<2 \mathrm{mSv} / \mathrm{y} \\
& \square \mathrm{mSv} / \mathrm{y}<\mathrm{E}(50)<3 \mathrm{mSv} / \mathrm{y} \\
& \square \mathrm{mSv} / \mathrm{y}<\mathrm{E}(50)<4 \mathrm{mSv} / \mathrm{y} \\
& \square \mathrm{mSv} / \mathrm{y}<\mathrm{E}(50)<5 \mathrm{mSv} / \mathrm{y} \\
& \mathrm{E}(50)>5 \mathrm{mSv} / \mathrm{y}
\end{aligned}
$$

Figure 1.- Dose distribution of long term (30 years) exposed workers to chronic inhalation of low enriched uranium

Highest intakes correspond to workers developing same specific tasks in the process of the fabrication of nuclear fuel elements for nuclear power plants with enriched uranium. Dosimetry information is contributing to improve the radiation protection conditions of the nuclear workforce in Juzbado.

\section{References}

1.- C.M. Castellani, J.W. Marsh, C. Hurtgen, E. Blanchardon, P. Berard, A. Giussani, M.A. Lopez, IDEAS Guidelines (Version 2) for the Estimation of Committed Doses from Incorporation Monitoring Data. EURADOS Report 2013-01.Braunschweig (2013).

2.-International Organization for Standardization. ISO 16638-Part 1 Radiation Protection: Monitoring and internal dosimetry for specific materials. Part 1: Uranium. ISO: Geneva (2015). 